\title{
Radioactive Air Emissions \\ Notice of Construction \\ HEPA Filtered Vacuum \\ Radioactive Air Emissions Units
}

Date Published

October 1997

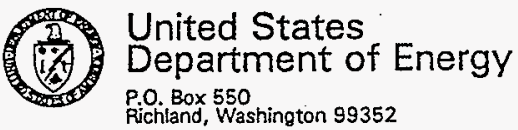

Richland, Washington 99352

Approved for Public Release 
TRADEMAPK DISCLAMER

Reference herein to any specific commerciel product, process, or service by trade neme, trademark, manufacturer, or otherwise, does not necessarily constitute or imply its

endorement, recorimendation, or favoring by the United

States Government or any agency thereof or its contractors or subcontractors.

This report has been reproduced from the best available copy. Available in peper copy and microfiche.

Aveilsble to the U.S. Department of Energy and its contractors from

Office of Scientific and Technical Information

P.O. Box 62

Oak Ridge, TN 37831

(615) 576-8401

Available to the public from the U.S. Department of Commerce Nationsl Techrical Information Senvice

5285 Port Royal Road

Springfiald, VA 22161

(703) 487-4650

Printed in the United Statem of Amarien

DISCLM-5.CHP (8-91) 


\section{RELEASE AUTHORIZATION}

Document Number:
DOE/RL-97-50, Rev. 0
Document Title:
Radioactive Air Emissions Notice of Construction for HEPA Filtered Vacuum Radioactive Air Emission Units

This document, reviewed in accordance with DOE Order 1430.1D, "Scientific and Technical Information Management," and DOE G 1430.1D-1, "Guide to the Management of Scientific and Technical Information," does not contain classified or sensitive unclassified information and is:

\section{APPROVED FOR PUBLIC RELEASE}

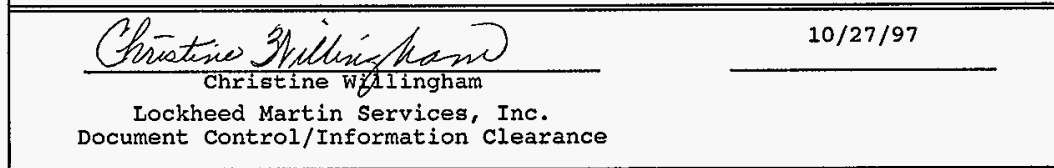

Reviewed for Applied Technology, Business Sensitive, Classified, Copyrighted, Export controlled, Patent, Personal/Private, Proprietary, protected CRADA, Trademark, Unclassified Controlled Nuclear Information.

LEGAI DISCLAIMER. This report was prepared as an account of work sponsored by an agency of the United states Government. Neither the United states Government nor any agency thereof, not any of their employees, nor any of their contractors, subcontractors or their employees, makes any warranty, express or implied, or assumes any legal liability or responsibility for the accuracy, completeness, or any third party's use or the results of such use of any information, apparatus, product, or process disclosed, or represents that its use would not infringe privately owned rights. Reference herein to any specific commercial product, process, or service by trade name, trademark, manufacturer, or otherwise, does not necessarily constitute or imply its endorsement, recommendation, or favoring by the United states Government or any agency thereof or its contractors or subcontractors. The views and opinions of authors expressed herein do not necessarily state or reflect those of the United states Government or any agency thereof. This report has been reproduced from the best available copy. Printed in the United states of America. 


A. Information Category
Speech or Presentation
$\square$ Full Paper
$\square$ Summary
$\square$ Abstract
$\square$ Multirnedia Presentation
$\square$ Voftware
$\square$ Oisual Aid
$\square$ Other Report

B. Document ID Number (include rev., vol., etc.)

DOE/RL-97-50, Rev. 0

C. List attachments (i.e., copyright permission, copyright transfer)

\section{Document Titie}

Radioactive Air Emissions Notice of Construction for HEPA Filtered Vacuum

Radioactive Air Emission Units

F. New or novel (patentable) subject matter?
If "Yes", has disclosure been submitted by WhC?

$\square$ No or Yes if "Yes", Disclosure No(s):

H. Copyrights? IN No or Yes If "Yes", attach permission.

2. COMPLETE THIS SECTION FOR ALL DOCUMENTS REOUIRING SUBMISSION TO OSTI

\begin{tabular}{|l|c|c|}
\hline A. Unclassified Category & UC -630 & B. Budget \& Reporting Code \\
\hline 3. COMPLETE THIS SECTION ONLY FOR A JOURNAL SUBMISSION
\end{tabular}

A. Title of Journal

4. COMPLETE THIS SECTION ONLY FOR A SPEECH OR' PRESENTATION

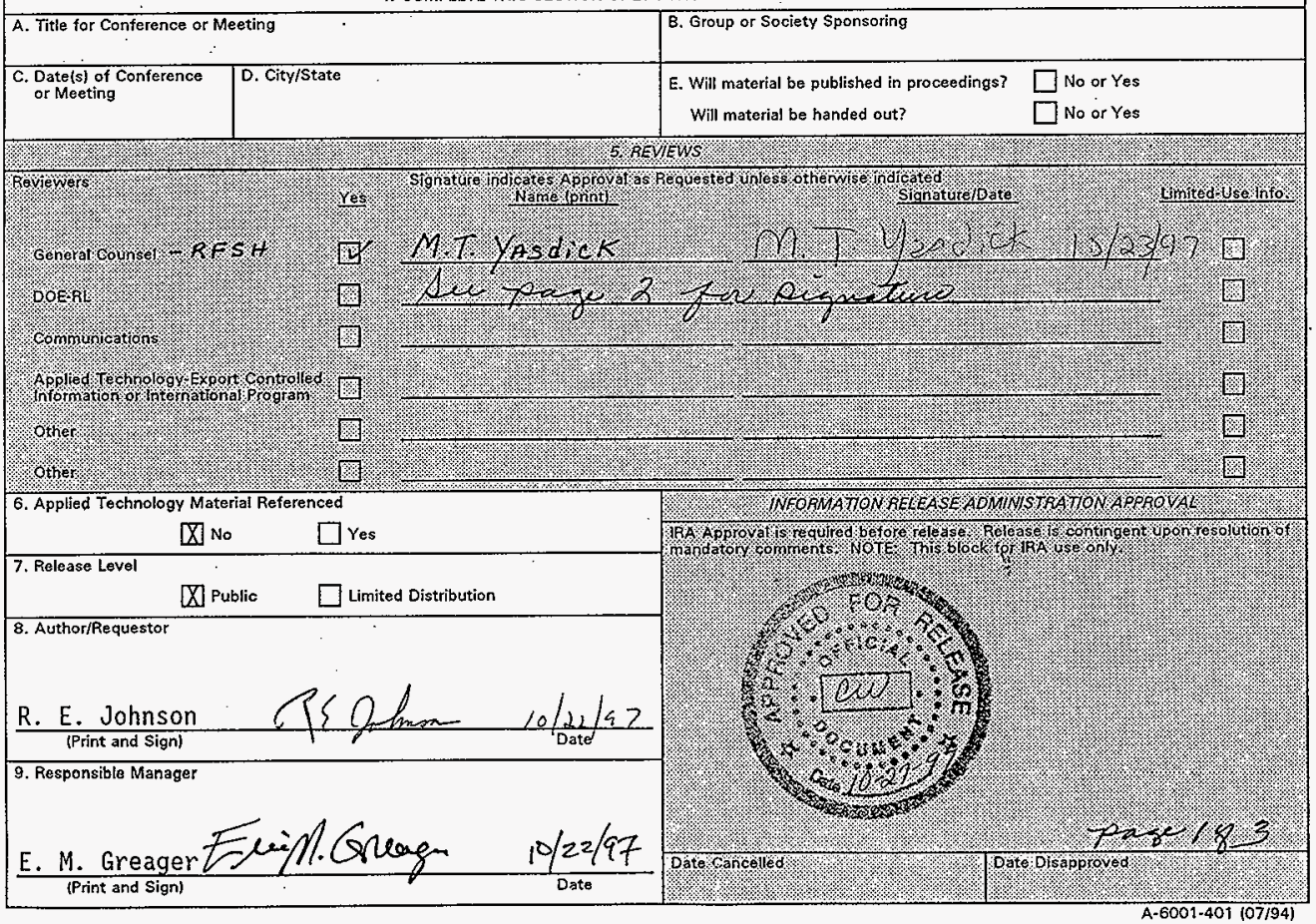


\begin{tabular}{l|l}
\hline Date Recoived by IRA & INFORMATION RELEASE REQUEST - (Long Form)
\end{tabular}

(GRAY SHADED AREAS NOT TO BE FILLEO IN BY INITIATOR)

\begin{tabular}{|l|l}
\hline \multicolumn{2}{|c|}{ A. Information Category } \\
\hline Speech or Presentation \\
$\square$ Full Paper \\
$\square$ Summary \\
$\square$ Journal Article \\
$\square$ Mustract \\
$\square$ Visual Aid \\
$\square$ Othedia Presentation \\
$\square$ Other Report \\
\hline
\end{tabular}

1. COMPLETE THIS SECTION FOR ALL DOCUMENTS

8. Document ID Number (includo rev., vol., otc.)

DOE/RL-97-50, Rev. 0

C. List astachments (i.e., copyright permission, copyright transfer)

D. Document Title

Radioactive Air Emissions Notice of Construction for HEPA Filtered Vacuum

Radioactive Air Emission Units

F. New or novel (patentable) subject matter?
If "Yes", has disclosure beon submitted by WHC? WN No or Yes

$\square$ No or Yes if "Yes", Disclosure No(s):

Wo or Yes and/or inventions?

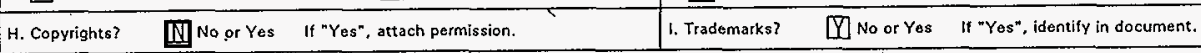

2. COMPLETE THIS SECTION FOR ALL DOCUMENTS REOUIRING SUEMISSION TO OSTI

\begin{tabular}{|c|c|c|c|}
\hline A. Unclassified Category & UC -630 & B. Budget \& Reporting Code & B\&R \\
\hline
\end{tabular}

A. Title of Journal

4. COMPLETE THIS SECTION ONLY FOR A SPEECH OR PRESENTATION

\begin{tabular}{|c|c|c|}
\hline \multicolumn{2}{|c|}{ A. Titlo tor Conference or Meoting } & B. Group or Socioty Sponsoring \\
\hline $\begin{array}{l}\text { C. Date(s) of Conferonce } \\
\text { or Meeting. }\end{array}$ & D. City/State & $\begin{array}{l}\text { E. Will material be published in proceodings? } \\
\text { Will material bo handod out? }\end{array}$ \\
\hline
\end{tabular}

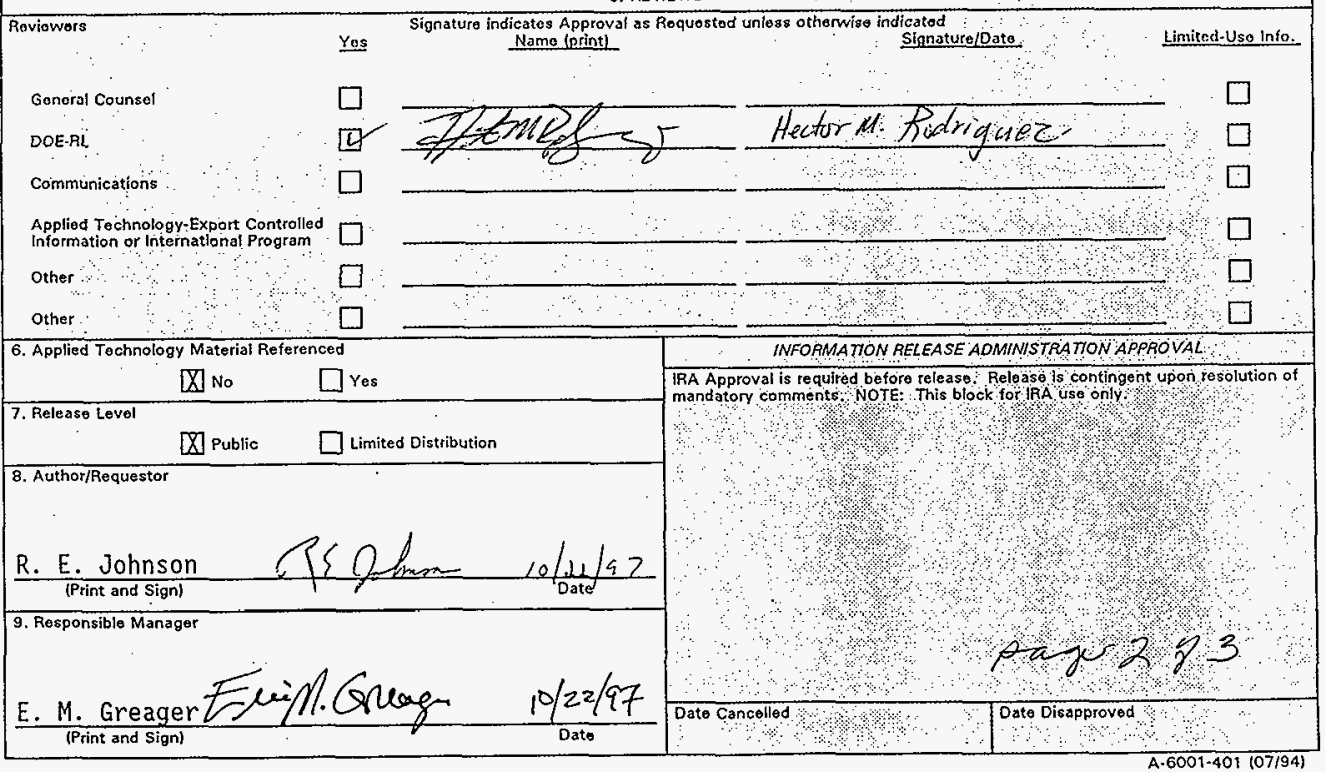


DOE/RL-97-50, Rev. 0

Document ID Number

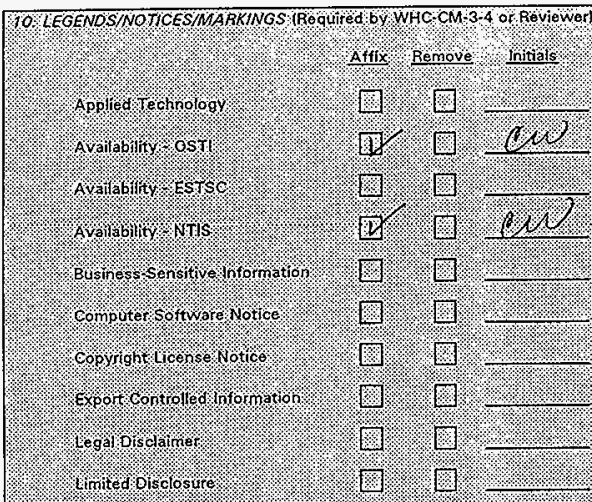

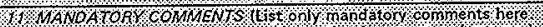

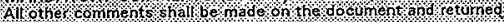

to the outtion

officialose only

Potentstatus

Predecisional information

Programmato Notice

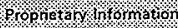

80 o.oserand Ose

Thesisioissetration

Tradomark Discioiner

ornex
Atix pemove Initials

\%

잘

잢

:

즌

ㄴ.

-1.

U.

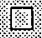

通

잔

ㄴ.

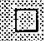

1).

?.

ㄴ.

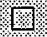

Reviewer: (prnto \& 6 ign)

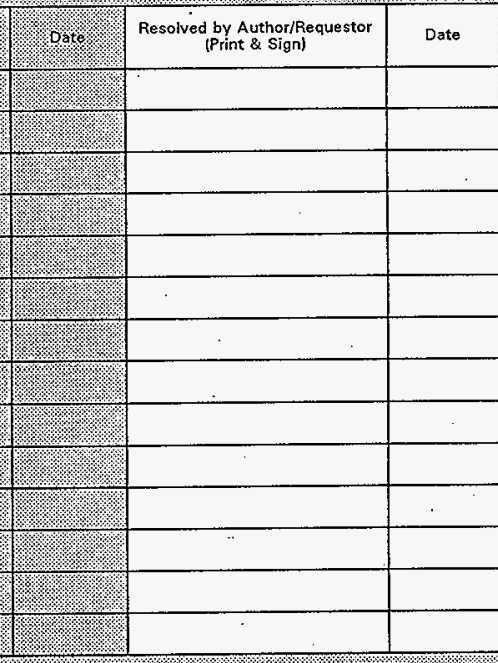

$$
3
$$

\%

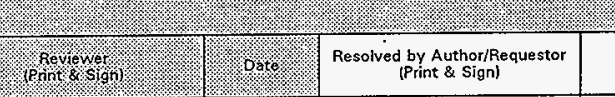




\section{CONTENTS}

TERMS

METRIC CONVERSION CHART . . . .................... vi

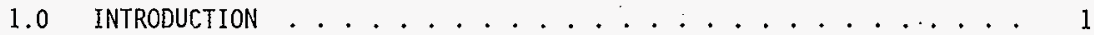

2.0 FACILITY LOCATION ..................... 2

3.0 RESPONSIBLE MANAGER (Requirement 2) ............. 3

4.0 TYPE OF PROPOSED ACTION (Requirenent 3$) \ldots \ldots . \ldots . \ldots 3$

5.0 STATE ENVIRONMENTAL POLICY ACT (Requirement 4) .......... 3

6.0 PROCESS DESCRIPTION (Requirement 5 and 7 ) ............. 3

7.0 ANNUAL POSSESSION QUANTITY AND PHYSICAL FORM

(Requirements $8,10,11$, AND 12) .................... 4

8.0 CONTROL SYSTEM (Requirement 6$) \ldots \ldots \ldots$

9.0 MONITORING SYSTEM $($ Requirement 9 ) ............... 6

10.0 RELEASE RATES (Requirement 13) . . . . . . . . . . 7

10.1 UNABATED EMISSIONS ................... 7

10.2 ABATED EMISSIONS . . . . . . . . . . . 7

11.0 OFFSITE IMPACT (Requirements 14 and 15) . . . . . . . . . . 8

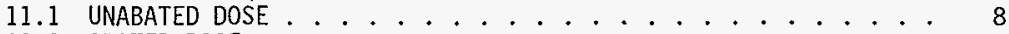

11.2 ABATED DOSE . . . . . . . . . . . . . . . . 9

12.0 FACILITY LIFETIME (Requirement 17 ) . . . . . . . . . . 10

13.0 TECHNOLOGY STANDARDS (Requirement 18 ) ........... 10

14.0 DISCUSSION OF AS LOW AS REASONABLY ACHIEVABLE CONTROL TECHNOLOGY

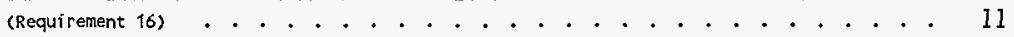

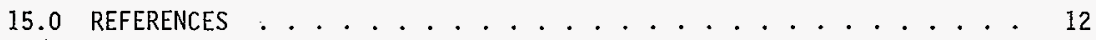

46 
APPENDICES A HIGH-EFFICIENCY PARTICULATE AIR FILTERED VACUUM UNIT
LISTING . . . . . . . . . . . . . . . . . . . . . . . . APP A-i

B HIGH-EFFICIENCY PARTICULATE AIR FILTERED VACUUM UNIT ASSOCIATED TOOLS FOR RADIOACTIVE CONTAMINATION REMOVAL . . . . APP B-i

c FACILITY POSSESSION LIMITS - SMEARABLE CONTAMINATION . . . . . APP $c-i$

D FACILITY POSSESSION LIMITS - FIXED CONTAMENATION REMOVAL . . . APP D- $i$

E EXAMPLE LOG SHEET FOR TRACKING HIGH-EFFICIENCY PARTICULATE AIR FILTERED VACUUM UNIT AND ANNUAL POSSESSION QUANTITIES $\cdots$ APP E- $i$

\section{TABLES}

1. Individual Facility Annua? Possession Quantities by Area for High-Efficiency Particulate Air Filtered Vacuum Unit Operations . . . 5

2. Maximum Abated Emissions for High-Efficiency Particulate Air Filtered Vacuum Unit Operations at Facilities by Area . . . . . 8

3. Unabated Dose Estimates from High-Efficiency Particulate Air Filtered Vacuum Unit Operations at Facilities by Area . . . . . . 9

4. Abated Dose Estimates from High-Efficiency Particulate Air Filtered Vacuum Unit Operations at Facilities by Area . . . . . . . . . . 10 
2

3

4 ALARA

5 ALARACT

$6 \mathrm{APQ}$

7

8

9

10

11

12

13

14 HEPA

15 HVU

16

17

18

19

20

21

22

23 WAC

24 WDOH

25

\section{TERMS}

as low as reasonably achievable

as low as reasonably achievable control technology annual possession quantity

best available radionuclide control technology

U.S. Department of Energy, Richland Operations Office

effective dose equivalent

high-efficiency particulate air

HEPA Filtered Vacuum Unit

maximaliy exposed ìndividual

notice of construction

total effective dose equivalent

Washington Administrative Code

Washington State Department of Health 
Into metric units

Out of metric units

\section{METRIC CONVERSION CHART}

\begin{tabular}{|c|c|c|c|c|c|}
\hline If you know & $\begin{array}{c}\text { Multiply } \\
\text { by }\end{array}$ & To get & If you know & $\begin{array}{c}\text { Multiply } \\
\text { by }\end{array}$ & To get \\
\hline \multicolumn{3}{|c|}{ Length } & \multicolumn{3}{|c|}{ Length } \\
\hline inches & 25.40 & millimeters & millimeters & 0.0393 & inches \\
\hline inches & 2.54 & centimeters & centimeters & 0.393 & inches \\
\hline feet & 0.3048 & meters & meters & 3.2808 & feet \\
\hline yards & 0.914 & meters & meters & 1.09 & yards \\
\hline miles & 1.609 & kilometers & kilometers & 0.62 & miles \\
\hline \multicolumn{3}{|c|}{ Area } & \multicolumn{3}{|c|}{ Area } \\
\hline $\begin{array}{l}\text { square } \\
\text { inches }\end{array}$ & 6.4516 & $\begin{array}{l}\text { square } \\
\text { centimeters }\end{array}$ & $\begin{array}{l}\text { square } \\
\text { centimeters }\end{array}$ & 0.155 & $\begin{array}{l}\text { square } \\
\text { inches }\end{array}$ \\
\hline square feet & 0.092 & $\begin{array}{l}\text { square } \\
\text { meters }\end{array}$ & $\begin{array}{l}\text { square } \\
\text { meters }\end{array}$ & 10.7639 & $\begin{array}{l}\text { square } \\
\text { feet }\end{array}$ \\
\hline $\begin{array}{l}\text { square } \\
\text { yards }\end{array}$ & 0.836 & $\begin{array}{l}\text { square } \\
\text { meters }\end{array}$ & $\begin{array}{l}\text { square } \\
\text { meters }\end{array}$ & 1.20 & $\begin{array}{l}\text { square } \\
\text { yards }\end{array}$ \\
\hline $\begin{array}{l}\text { square } \\
\text { miles }\end{array}$ & 2.59 & $\begin{array}{l}\text { square } \\
\text { kilometers }\end{array}$ & $\begin{array}{l}\text { square } \\
\text { kilometers }\end{array}$ & 0.39 & $\begin{array}{l}\text { square } \\
\text { miles }\end{array}$ \\
\hline acres & 0.404 & hectares & hectares & 2.471 & acres \\
\hline \multicolumn{3}{|c|}{ Mass (weight) } & \multicolumn{3}{|c|}{ Mass (weight) } \\
\hline ounces & 28.35 & grams & grams & 0.0352 & ounces \\
\hline pounds & 0.453 & kilograms & kilograms & 2.2046 & pounds \\
\hline short ton & 0.907 & metric ton & metric ton & 1.10 & short ton \\
\hline \multicolumn{3}{|c|}{ Volume } & \multicolumn{3}{|c|}{ Volume } \\
\hline $\begin{array}{l}\text { fluid } \\
\text { ounces }\end{array}$ & 29.57 & milliliters & mi11i1iters & $0 . \overline{03}$ & $\begin{array}{l}\text { fluid } \\
\text { ounces }\end{array}$ \\
\hline quarts & 0.95 & Titers & Jiters & 1.057 & quarts \\
\hline gallons & 3.79 & Titers & Titers & 0.26 & gallons \\
\hline cubic feet & 0.03 & $\begin{array}{l}\text { cubic } \\
\text { meters }\end{array}$ & $\begin{array}{l}\text { cubic } \\
\text { meters }\end{array}$ & 35.3147 & cubic feet \\
\hline cubic yards & 0.76456 & $\begin{array}{l}\text { cubic } \\
\text { meters }\end{array}$ & $\begin{array}{l}\text { cubic } \\
\text { meters }\end{array}$ & 1.308 & $\begin{array}{l}\text { cubic } \\
\text { yards }\end{array}$ \\
\hline \multicolumn{3}{|c|}{ Temperature } & \multicolumn{3}{|c|}{ Temperature } \\
\hline Fahrenheit & $\begin{array}{l}\text { subtract } \\
32 \text { then } \\
\text { multiply } \\
\text { by } 5 / 9 \text { ths }\end{array}$ & Celsius & Celsius & $\begin{array}{l}\text { multiply } \\
\text { by } \\
9 / 5 \text { ths, } \\
\text { then add } \\
32\end{array}$ & Fahrenheit \\
\hline \multicolumn{3}{|c|}{ Force } & \multicolumn{3}{|c|}{ Force } \\
\hline $\begin{array}{l}\text { pounds per } \\
\text { square inch }\end{array}$ & 6.895 & kilopascals & kilopascals & $\begin{array}{l}1.4504 \times \\
10^{-4}\end{array}$ & $\begin{array}{l}\text { pounds per } \\
\text { square } \\
\text { inch }\end{array}$ \\
\hline
\end{tabular}

Source: Engineering Unit Conversions, M. R. Lindeburg, PE., Second Ed., 1990, Professional Publications, Inc., Belmont, California. 


\section{RADIOACTIVE AIR EMISSIONS \\ NOTICE OF CONSTRUCTION \\ HEPA FILTERED VACUUM RADIOACTIVE AIR EMISSION UNITS}

\subsection{INTRODUCTION}

This notice of construction (NOC) requests a categorical approval for construction and operation of certain portable high-efficiency particulate air (HEPA) filtered vacuum radionuclide airborne emission units (HVUs). Approval of this NOC application is intended to allow operation of the HVUs without prior project-specific approval.

This NOC does not request replacement or supersedence of any previous agreements/approvals by the Washington State Department of Health (WDOH) for the use of vacuums on the Hanford Site. These previous agreements/approvals include the approved NOCs for the use of EuroClean HEPA vacuums at the T PIant Complex and the Kelly Decontamination System at the Plutonium-Uranium Extraction (PUREX) Plant.

Also, this NOC does not replace or supersede the agreement reached regarding the use of HEPA hand-held/shop-vacuum cleaners for routine cleanup activities conducted by the Environmental Restoration Project. Routine cleanup activities are conducted during the surveillance and maintenance of inactive waste sites (Radioactive Area Remedial Action Project) and inactive facilities. HEPA hand-held/shop-vacuum cleaners are used to clean up spot surface contamination areas found during outdoor radiological field surveys, and to clean up localjzed radiologically contaminated material (e.g., dust, dirt, bird droppings, animal feces, liquids, insects, spider webs, etc.). This agreement, documented in the October 12, 1994 Routine Meeting Minutes, is based on routine cleanup consisting of spot cleanup of low-level contamination provided that, in each case, the source term potential would be below 0.1 millirem per year.

This application is intended to request sitewide approval for the new activities, and provide an option for any facility on the site to use this approval, within the terms of this NOC. The HVUs used in accordance with this NOC will support reduction of radiological contamination at various locations on the Hanford Site.

Radiation Protection - Air Emissions, Washington Administrative Code (WAC) 246-247, require that the WDOH approve an NOC application before construction or modification of any emission unit that would release airborne radioactivity. This includes changes in the isotopic makeup of the source term or replacement of emission control equipment, which might contribute to an increase in the offsite dose from a licensed facility.

Reduction of radiologically contaminated areas by HEPA vacuums is a current need. The U.S. Department of Energy, Richland Operations Office (DOE-RL) potentially could generate numerous monthiy applications. The existing case-by-case NOC approval process delays efforts to complete such 
1 activities in an effective and timely manner, as WDOH requires review and to request a single categorical license that identifies limits and conditions of operations such as the specified HEPA filtered vacuum units. Under a categorical approval, cleanup activities could proceed without delay.

The DOE-RL will submit an annual report to the WDOH summarizing the log sheets maintained on any of the HVUs that were used under the categorical approva1. The report will supply information needed to maintain oversight of the operations of HVUs on the Hanford Site.

This NOC includes a general description of the types of HVUs, tracking mechanisms, emissions control systems, and individual facility (e.g., B Plant Complex, C Tank Farm, SX Tank Farm, 'T Plant Complex, 100-K East Basin, 100-K West Basin, 324 Building, 340 Complex, etc.) or activity [e:g., decontamination and decommissioning (D\&D) of a building] possession iimits for all radioactive material potentially removed by HWUs. All emission estimates used in this NOC are based on hypothetical worst-case data (no controls in place). These data are used to demonstrate how emission estimates are calculated. The tracking mechanisms will be performed and monitoring will be conducted in compliance with both federal and state regulations.

HVUs included in the scope of this application are described in Appendix A. Appendix A contains a list of the types of HVUs for use on the Hanford Site that have been identified to date and includes the model, flow rates, and characteristics. HEPA vacuum-assisted (shrouded) power tools are described in Appendix B. HVUs included in the scope of this NOC must meet the requirements of the Hanford Site Radiological Control Manual (HSRCM), Article 464. When other HVUs and shrouded tools are placed in service, this information will be included in the annual report.

If a HVU is used for established routine work at an existing source whose facility stack is registered with the $W D O H$, and the activity emissions are vented through that stack, the unit is not required to comply with this application. The use of HEPA filtered vacuums that are described as part of an activity identified in a separate, existing NOC also are excluded.

\subsection{FACILITY LOCATION}

\section{U.S. Department of Energy, Richland Operations Office} Hanford Site Richland, Washington 99352

The HVUs could be located at any facility located on the Hanford Site. These units are portable and are used in various locations as needed. 


\subsection{RESPONSIBLE MANAGER (Requirement 2)}

Mr. J. E. Rasmussen, Division Director

Office of Environmenta] Assurance,

Policy, and Permits

U.S. Department of Energy, Richland Operations Office

P.0. Box 550

Richland, Washington 99352

\subsection{TYPE OF PROPOSED ACTION (Requirement 3)}

This proposed action serves involves use of specified HVUs located and operated on the Hanford Site, and represents establishment of unregistered, portable and temporary, insignificant emission units.

For the purposes of estimating (modeling) offsite exposures for this application, all applicable HVU emissions at an individual facility (e.g., B Plant Complex, C Tank Farm, SX Tank Farm, T Plant Complex, 100-K East Basin, 100-K West Basin, 324 Building, 340 Complex, etc.) or activity (e.g., D\&D of a building) will be considered as a single emission point for that facility.

\subsection{STATE ENVIRONMENTAL POLICY ACT (Requirement 4)}

The use of HVUS is categorically exempt from the SEPA process by reference in WAC 246-03-020.

\subsection{PROCESS DESCRIPTION (Requirement 5 and 7 )}

HVUs are portable cleaners with exhaust flow rates ranging from 50 to 300 cubic feet per minute. The units control radionuclide emissions by providing filtered vacuuming for surfaces that are radioactively contaminated.

HVUs fall into two categories of use for this application, those used for the reduction of smearable contamination and those used to reduce fixed contamination. For smearable contamination, the use of HVUs is limited to reduction of contamination on hard surfaces (e.g., concrete surfaces, permanently installed metal equipment such as risers, ventilation system components, piping, etc.). Soil matrices are excluded from this NOC. Smearable contamination on these hard surfaces will not exceed limits established in the Radiation Control Manual (HSRCM-1, Rev. 2). These limits, if exceeded, require the affected area to be posted as a high contamination area. The ijmits are 2,000 disintegrations per minute per 100 square centimeters $\left(\mathrm{dpm} / 100 \mathrm{~cm}^{2}\right.$ ) alpha $(\alpha)$ contamination and $100,000 \mathrm{dpm} / 100 \mathrm{~cm}^{2}$ beta/gamma $(\beta / V)$ contamination (refer to Appendix $C$ ). 
An exception to these limits is restricted to spot surface contamination areas found during outdoor radiological field surveys, and to clean up localized, radiologically contaminated material (e.g., dust, dirt, bird droppings, animal feces, insects, spider webs, tumbleweed fragments, etc.). These types of materials could have $\beta / V$ contamination levels exceeding $1 \mathrm{million} \mathrm{dpm} / 100 \mathrm{~cm}^{2}$, but are very localized (i.e., a few square meters, rather than hundreds of square meters) and could occur in contamination areas, buffer zones, and clean zones. This exception does not apply to areas normally posted as high contamination areas.

The second category of use is for reduction of fixed contamination, involving the removal and/or penetration of contaminated surfaces. This category of use includes using HVUs and associated shrouded tools for sanding, stripping, spalling, drilling, and cutting operations. Limits in areas of fixed contamination to ensure compliance with this NOC will be established before these tools are used (refer to Appendix D).

\subsection{ANNUAL POSSESSION QUANTITY AND PHYSICAL FORM \\ (Requirements $8,10,11$, AND 12)}

The annual possession quantity (APQ) that an HVU handies varies from activity to activity. In many cases, the exact inventory is unknown at the beginning of the activity. To assist operators of the HVUs to determine the requirements for compliance with federal and state regulations, facility $A P Q S$ were derived for individual facilities (e.g., B Plant Complex, C Tank Farm, SX Tank Farm, T Plant Complex, 100-K East Basin, 100-K West Basin, 324 Building, 340 Complex, etc.) or activities (e.g., D\&D of a building) within each of the major areas where HVUs could be operated.

The APQs were calculated for a maximum annual combined use of HVUs by an individual facility or activity. The assumption in calculating the APQs was that the 0.1 millirem per year criteria is used, as a beginning point and the source term that could be handled annually is back calculated very conservatively. The approach taken was to calculate the maximum area (at contamination levels of $2,000 \mathrm{dpm} / 100 \mathrm{~cm}^{2} \alpha$ contamination and $100,000 \mathrm{dpm} / 100 \mathrm{~cm}^{2} \beta / Y$ contamination) that would have a dose potential of 0.1 millirem per year. The number of curies of plutonium-239/240 and strontium-90 that would be present in that maximum area was calculated, assuming that the entire area was at both those contamination levels. This process was used for each of the major areas to calculate the APQs, using the appropriate unit dose factors. The recommended dose assessment methodology, for comparison with individual facility $A P Q s$, and example calculations are found in Appendices $C$ and $D$.

Table 1 lists the APQ that the HVUs theoretically could handle for combined smearable and fixed contamination at individual facilities in each of the major areas. To determine the APQs, a physical form of particulates was assumed. Further, because vacuuming was involved, a release fraction of I conservatively was assumed (for all material removed). 
The APQS for the isotopes are shown in Table 1 . Please note the 1 imits are on an annual basis for any individual facility within the 1isted area. The APQs in Table 1 are based on hypothetical worst-case source terms that a1? HVUs at an individual facility combined could handle during a year and remain below 0.1 millirem per year unabated dose.

When a user determines the source term (i.e., APQ) for HVU use, the user can conservatively estimate total activity by assuming that all $\alpha$ contamination is plutonium-239/240 and that all $\beta / \gamma$ contamination is strontium-90. If specific isotopic information is available and used, the user wi11 take into consideration all radionuclides that would potentially contribute 10 percent of the total effective dose equivalent (TEDE) to the maximum exposed individual (MEI) (i.e. cesium-137 or americium-241 may be the appropriate isotopes to use at certain facilities).

Table 1. Individual Facility Annual Possession Quantities by Area for High-Efficiency Particulate Air Filtered Vacuum Unit Operations.

\begin{tabular}{|l|c|c|}
\hline \multicolumn{1}{|c|}{ Area } & $\begin{array}{c}\text { Annual possession } \\
\text { quantity } \\
\text { a contamination } \\
\text { (as plutonium-239/240) } \\
\text { (curies per year) }\end{array}$ & $\begin{array}{c}\text { Annual possession } \\
\text { quantity } \\
\text { B/y contamination } \\
\text { (as strontium-90) } \\
\text { (curies per year) }\end{array}$ \\
\hline \hline 100 Area & $7.55 \mathrm{E}-04$ & $3.81 \mathrm{E}-02$ \\
\hline 200 East Area & $4.57 \mathrm{E}-03$ & $2.30 \mathrm{E}-01$ \\
\hline 200 West Area & $7.70 \mathrm{E}-03$ & $3.88 \mathrm{E}-01$ \\
\hline 300 Area & $2.29 \mathrm{E}-04$ & $1.16 \mathrm{E}-02$ \\
\hline 400 Area & $8.41 \mathrm{E}-04$ & $4.24 \mathrm{E}-02$ \\
\hline
\end{tabular}

\subsection{CONTROL SYSTEM (Requirement 6)}

Annually the HVUs are field tested, requiring an aerosol test/efficiency test or equivalent pass/fail criteria of 99.95 percent for particles of 0.3 micron median diameter. In addition, the HVUs filtration systems are tested whenever the configuration is modified and/or the filtration system is opened. 
A smear of the exhaust port will be conducted before and after each use of HVUs. If the exhaust port smear is positive, the unit will be tagged and removed from service.

\subsection{MONITORING SYSTEM (Requirement 9)}

Each individual facility is responsible for tracking/recording the use of HVUs. As required by federal and state regulations, records will be maintained by the individual facility and kept for at least 5 years. Procedures for using HVUs will be in place and employees will become familiar with them before use.

The method used for monitoring is the log sheet, functionally equivalent to the one shown in Appendix $E$, used to track HVUs and the calculations (examples given in Appendices $C$ and D) to determine maximum expected annual emissions. When implementing the use of HVUs, the responsible personnel (operators) $\mathrm{log}$ the following information. Additional information can be tailored for the individual facility, such as the Table 1 APQs, and curies to date.

- Location of operation and make and model of unit

- Date(s) of operations

- Purpose of operation (or work package number)

- Air emissions source constituents (if other than plutonium-239 and strontium-90)

- Area cleaned (in square meters)

- Maximum contamination level encountered or analysis results

- Potential radionuclide releases (in curies, per Appendices $C$ and/or D)

- Results of smears on the exhaust port(s) positive (in $\mathrm{dpm} / 100 \mathrm{~cm}^{2}$ ) or negative.

A copy of the log sheets will be maintained by the facility (at least 5 years) and a report submitted annually to the WDOH on March 15 . The March 15 submittal will consist of a summary of HVU operations performed in accordance with this NOC from January through December of the previous year. The estimated emissions from the units will be reviewed and summarized in the annual radionuclide air emissions report for the Hanford Site.

The recordkeeping is not in lieu of required monitoring for health, safety, DOE/RL, or contractor requirements. This recordkeeping is intended to document periodic confirmatory monitoring for the emission units. All associated emissions wil1 be reported as part of the annual radionuclide air emissions report. This recordkeeping also supports the reduction of NOC 
1 appiications and notification submittals required by federal and state

2 regulations.

3

4

\subsection{RELEASE RATES (Requirement 13)}

This section provides information regarding the hypothetical emission release rates from the HVUs that would occur under normal use, but without the emission control systems (the HEPA filter) in place. Also included is the total effective dose equivalent (TEDE) to the nearest facility receptor resulting from such unabated emissions.

\subsection{UNABATED EMISSIONS}

Table 1 lists the annual possession limits for HVU usage by an individual facility (e.g., B Plant Complex, C Tank Farm, SX Tank Farm, T Plant Complex, 100-K East Basin, 100-K West Basin, 324 Building, 340 Complex, etc.) or activity (e.g., D\&D of a building) in each of the major areas on the Hanford Site. Because vacuuming operations are involved, a release fraction of 1 was used. The facility APQs shown in Table 1 are equal to the maximum unabated emissions for HVU usage by an individual facility in each of the major areas on the Hanford Site.

\subsection{ABATED EMISSIONS}

Table 2 lists the abated air emissions for HVU usage by an individua? facility or activity in each of the major areas on the Hanford Site. HEPA filtration is the control equipment used on each of the units. A treatment factor of 2,000 (WHC-EP-0498) was used when calculating the control efficiency of the HEPA systems. 


\begin{tabular}{|c|c|c|c|c|c|}
\hline Area & $\begin{array}{l}\text { Annual unabated } \\
\text { emissions } \\
a \text { contamination (as } \\
\text { plutonium- } 239 / 240 \text { ) } \\
\text { (curies per year) }\end{array}$ & $\begin{array}{l}\text { Annual unabated } \\
\text { emissions } \\
\beta / \gamma \text { contamination } \\
\text { (as strontium- } 90 \text { ) } \\
\text { (curies per year) }\end{array}$ & $\begin{array}{c}\text { HEPA } \\
\text { control } \\
\text { treatment } \\
\text { factor }\end{array}$ & $\begin{array}{c}\text { Annual abated } \\
\text { emissions } \\
\sigma \text { contamination (as } \\
\text { plutoniun-23\%/240) } \\
\text { (curies per year) }\end{array}$ & $\begin{array}{c}\text { Annual abated } \\
\text { emissions } \\
\beta / y \text { contamination } \\
\text { (as strontiun-90) } \\
\text { (curies per year) }\end{array}$ \\
\hline 100 Area & 7.55 E-04 & $3.81 \mathrm{E}-02$ & $2 E+03$ & $3.78 \mathrm{E}-07$ & $1.91 E-05$ \\
\hline $\begin{array}{l}200 \text { East } \\
\text { Area }\end{array}$ & $4.57 E-03$ & 2.30 E- 01 & $2 E+03$ & $2.29 \varepsilon-06$ & . $\quad 1.15$ E-04 \\
\hline $\begin{array}{l}200 \text { West } \\
\text { Area }\end{array}$ & $7.70 \mathrm{E}-03$ & 3.88 E-01. & $2 E+03$ & $3.85 \varepsilon-06$ & 1.94 E-04 \\
\hline 300 Area. & 2.29 E-04 & $1.16 \mathrm{E}-02$ & $2 E+03$ & $1.15 \mathrm{E} \times 07$ & 5.80 E-06 \\
\hline 400 Area & 8.41 E- 04 & 4.24 E-02 & $2 E+03$ & $4.21 E-07$ & 2.12 E-05 \\
\hline
\end{tabular}

\subsection{OFFSITE IMPACT (Requirements 14 and 15)}

Hanford Site air emissions from all point sources resulted in an EDE of $2.0 \mathrm{E}-3$ millirem per year to the MEI in 1996 (DOE/RL-96-37). The EDE from all Hanford Site air emissions, including point sources, diffuse and fugitive sources, radon emissions, and thoron emissions, was determined to be $3.9 \mathrm{E}-2$ millirem per year to the MEI in 1996. The anticipated offsite dose impact as a result of the HVUs in conjunction with other operations on the Hanford Site will remain well below the National Emission Standard of 10 millirem per year.

\subsection{UNABATED DOSE}

The unabated dose to the nearest receptor located at the Hanford Site boundary for an individual facility at each of the areas is shown in Table 3 . The facility radioactive annual possession 7 imits in Table 1 were used, along with the dose factors for each of the areas on the Hanford Site. The unit dose factors included were submitted previously to the WDOH (WHC-EP-0498). The information required to develop the unit dose factors from the U.S. Environmental Protection Agency approved Clean Air Assessment Package 1988 (CAP-88) computer code also was included in "Unit Dose Calculation Methods Summary of Facility Effluent Monitoring Plan Determinations"

49 (WHC-EP-0498). Note that because the mainframe version of CAP-88 was used in 50 this NOC, rather than the PC version 1.0 of CAP-88, the APQs were cut in half 51 for the 200 East, 200 West, and 300 Areas in Tables 1 through 4 to provide 52 additional conservatism. 


\subsection{ABATED DOSE}

The abated dose to the nearest receptor located at the Hanford Site boundary for an individual facility or activity within each of the areas is shown in Table 4 . The unit dose factors included in the table are described in Section 11.1.

Table 3. Unabated Dose Estimates from High-Efficiency Particulate Air Filtered Vacuum Unit Operations at Facilities by Area.

\begin{tabular}{|c|c|c|c|c|c|}
\hline Area & $\begin{array}{c}\text { Annual unabated } \\
\text { emissions } \\
\alpha \text { contamination (as } \\
\text { plutonium-239/240) } \\
\text { (curies per year) }\end{array}$ & $\begin{array}{l}\text { Annual unabated } \\
\text { enissions } \\
\beta / \gamma \text { contamination } \\
\text { (as strontium- } 90 \text { ) } \\
\text { (curies per year) }\end{array}$ & $\begin{array}{l}\text { CAPB8 unit } \\
\text { Dose Factor } \\
\text { (mitl irem } \\
\text { per curie) } \\
\text { Ist: } \alpha \\
\text { 2nd: } \beta / Y\end{array}$ & $\begin{array}{c}\text { Annual } \\
\text { unabated dose } \\
\text { a contamination (as } \\
\text { plutonium-239/240) } \\
\text { (millirem per year) }\end{array}$ & $\begin{array}{c}\text { Annuat } \\
\text { unabated dose } \beta / \gamma \\
\text { contamination } \\
\text { (as strontium-90) } \\
\text { (millirem per } \\
\text { year) }\end{array}$ \\
\hline \multirow[t]{2}{*}{100 Area } & \multirow[t]{2}{*}{$7.55 \varepsilon-04$} & \multirow[t]{2}{*}{$3.81 E-02$} & \multirow[t]{2}{*}{$\begin{array}{l}1.28 E+02 \\
6.45 E-02\end{array}$} & $9.66 E-02$ & $2.46 E-03$ \\
\hline & & & & Total Dose: & $9.91 E-02$ \\
\hline \multirow[t]{2}{*}{$\begin{array}{l}200 \text { East } \\
\text { Area }\end{array}$} & \multirow[t]{2}{*}{$4.57 E-03$} & \multirow[t]{2}{*}{$2.30 \mathrm{E}-01$} & \multirow[t]{2}{*}{$\begin{array}{l}8.67 E+00 \\
4.38 E-02\end{array}$} & $3.96 \mathrm{E}-02$ & $1.01 \mathrm{E}-02$ \\
\hline & & & & Total Dose: & 4.97 E-02 \\
\hline \multirow[t]{2}{*}{$\begin{array}{l}200 \text { West } \\
\text { Area }\end{array}$} & \multirow[t]{2}{*}{7.70 E-03 } & \multirow[t]{2}{*}{$3.88 \mathrm{E}+01$} & \multirow[t]{2}{*}{$\begin{array}{l}5.15 E+00 \\
2.60 E-02\end{array}$} & 3.97 E-02 & $1.01 \mathrm{E}-02$ \\
\hline & & & & Total Dose: & $4.98 \mathrm{E}-02$ \\
\hline \multirow[t]{2}{*}{300 Агеа } & \multirow[t]{2}{*}{$2.29 \mathrm{E}-04$} & \multirow[t]{2}{*}{$1.16 \mathrm{E}-02$} & \multirow[t]{2}{*}{$\begin{array}{l}1.73 E+02 \\
8.72 E-01\end{array}$} & $3.96 \mathrm{E}-02$ & 1.01 E-02 \\
\hline & & & & Total Dose: & $4.97 \mathrm{E}-02$ \\
\hline \multirow[t]{2}{*}{400 Area } & \multirow[t]{2}{*}{$8.41 E-04$} & \multirow[t]{2}{*}{$4.24 E-02$} & \multirow[t]{2}{*}{$\begin{array}{l}1.15 E+02 \\
5.80 E-02\end{array}$} & $9.67 \mathrm{E}-02$ & 2.46 E-03 \\
\hline & & & & Total Dose: & $9.92 \mathrm{E}-02$ \\
\hline
\end{tabular}




\begin{tabular}{|c|c|c|c|c|c|}
\hline Área & $\begin{array}{c}\text { Annual abated } \\
\text { emissions } a \\
\text { contamination (as } \\
\text { plutonium- } 239 / 240 \text { ) } \\
\text { (curies per year) }\end{array}$ & $\begin{array}{c}\text { Annual abated } \\
\text { emissions } \beta / Y \\
\text { contamination (as } \\
\text { strontium-90) } \\
\text { (curies per year) }\end{array}$ & $\begin{array}{l}\text { CAP88 unit } \\
\text { dose factor } \\
\text { (millirem } \\
\text { per curie) } \\
\text { 1st: } \alpha \\
\text { 2nd: } \beta / Y\end{array}$ & $\begin{array}{c}\text { Annual } \\
\text { abated dose } \\
\text { a contamination (as } \\
\text { plutoniun-239/240) } \\
\text { (millirem per year) }\end{array}$ & $\begin{array}{c}\text { Annual } \\
\text { abated dose } \\
\beta / Y \text { contanination } \\
\text { (as stront ium }-90) \\
\text { (mill irem per year) }\end{array}$ \\
\hline \multirow[t]{2}{*}{100 Area } & \multirow[t]{2}{*}{3.78 E-07 } & \multirow[t]{2}{*}{$1.91 \mathrm{E}-05$} & \multirow{2}{*}{$\begin{array}{l}1.28 \mathrm{E}+02 \\
6.45 \mathrm{E}-02\end{array}$} & $4.84 E-05$ & $1.23 \mathrm{E}-06$ \\
\hline & & & & Total Dose: & $4.96 \mathrm{E}-05$ \\
\hline \multirow[t]{2}{*}{$\begin{array}{l}200 \text { East } \\
\text { Area }\end{array}$} & \multirow[t]{2}{*}{2.29 E-06 } & \multirow[t]{2}{*}{$1.15 \mathrm{E}-04$} & \multirow[t]{2}{*}{$\begin{array}{l}8.67 \mathrm{E}+00 \\
4.38 \mathrm{E}-02\end{array}$} & 1.99 E-05 & 5.04 E-06 \\
\hline & & & & Total Dose: & $2.49 E-05$ \\
\hline \multirow[t]{2}{*}{$\begin{array}{l}200 \text { West } \\
\text { Area }\end{array}$} & \multirow[t]{2}{*}{3.85 E-06 } & \multirow[t]{2}{*}{1.94 E-04 } & \multirow[t]{2}{*}{$\begin{array}{l}5.15 E+00 \\
2.60 E-02\end{array}$} & $1.98 E-05$ & 5.04 E-06 \\
\hline & & & & Total Dose: & $2.48 \mathrm{E}-05$ \\
\hline \multirow[t]{2}{*}{300 Area } & \multirow[t]{2}{*}{1.15 E-07 } & \multirow[t]{2}{*}{$5.80 \mathrm{E}-06$} & \multirow{2}{*}{$\begin{array}{l}1.73 E+02 \\
8.72 E-01\end{array}$} & 1.99 E-05 & $5.06 E-06$ \\
\hline & & & & Total Dose: & $2.50 \mathrm{E}-05$ \\
\hline \multirow[t]{2}{*}{400 Area } & \multirow[t]{2}{*}{$4.21 \mathrm{E}-07$} & \multirow[t]{2}{*}{$2.12 \mathrm{E}-05$} & \multirow{2}{*}{$\begin{array}{l}1.15 \mathrm{E}+02 \\
5.80 \mathrm{E}-02\end{array}$} & $4.84 \mathrm{E}-05$ & $1.23 \mathrm{E}-06$ \\
\hline & & & & Total Dose: & $4.96 \mathrm{E}-05$ \\
\hline
\end{tabular}

\subsection{FACILITY LIFETIME (Requirement 17)}

Environmental cleanup efforts on the Hanford Site are ongoing. Estimated lifetime of the HVUs ranges from 5 to 10 years, depending on type and frequency of use.

\subsection{TECHNOLOGY STANDARDS (Requirement 18)}

The potential TEDE received by the offsite hypothetical nearest receptor, resulting from the proposed HVU operations at each of the individual

facilities (e.g., B Plant Complex, C Tank Farm, SX Tank Farm, T Plant Complex, 100-K East Basin, 100-K West Basin, 324 Building, 324 Complex, etc.) or each of the activities (e.g., D\&D of a building) is less than 0.1 millirem per year. For the purpose of estimating (modeling) offsite exposures for this application, all applicable HVU emissions at an individual facility will be considered a single emission point.

Control technology standards listed under WAC 246-247-110(18) have been considered. The HVUs have been designed and constructed in conformance with ASME/ANSI AG-1 and ASME/ANSI N509. Testing and maintenance of HEPA filters 52 are conducted using applicable methods prescribed by ASME/ANSI N510, Nuclear 


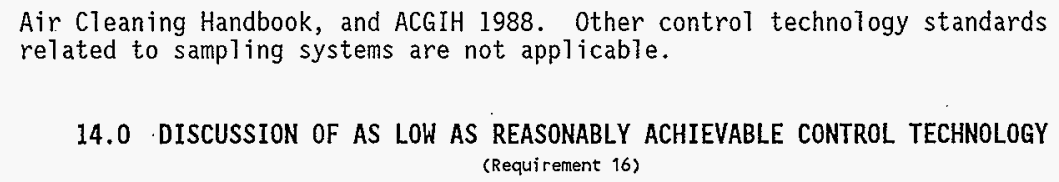

\subsection{DISCUSSION OF AS LOW AS REASONABLY ACHIEVABLE CONTROL TECHNOLOGY} (Requirement 16)

It is proposed that the HEPA filtration systems be approved, as described in Section 8.0 of the NOC, as low as reasonably achievable control technology (ALARACT) for the support of reduction of radioactive contamination at various locations on the Hanford Site. This discussion of ALARACT does not present a detailed evaluation of all of the available radionuclide control technologies nor does it rank the relative benefits with respect to the environment, economical, and energy impacts of each technology. The WDOH has stated that HEPA filters generaliy are accepted as best available radionuclide control

17 technology (BARCT) for particulate radionuclide air emissions. HEPA filter 18 units have been used extensively on the Hanford Site to effectively control 19 particulate radionuclide air emissions. 
DOE/RL-97-43, Radionuclide Air Emissions Report for the Hanford Site, Calendar Year 1996, U.S. Department of Energy, Richland Operations Office, Richland, Washington.

HSRCM-1, Rev.2, Hanford Site Radiological Contro7 Manua7, Hanford Radiological Control Forum, Richland, Washington.

WHC-EP-0498, Unit Dose Calculation Methods Summary of Facility Effluent Monitoring Plan Determinations, Westinghouse Hanford Company, Richland, Washington. 


\section{APPENDIX A}

HIGH-EFFICIENCY PARTICULATE AIR FILTERED VACUUM UNIT LISTING 
DOE/RL-97-50, Rev. 0

$10 / 97$

1

2

3

4

5

This page intentionally left blank. 
1 Table A-1. HEPA Filtered Vacuum Cleaners Used on the Hanford Site.

2

\begin{tabular}{|c|c|c|c|}
\hline Make & Mode1 & $\begin{array}{c}\text { Flowrate } \\
\text { (CFM) }\end{array}$ & Remarks \\
\hline \multicolumn{4}{|c|}{$\begin{array}{l}\text { Kelly Decontamination } \\
\text { System }\end{array}$} \\
\hline Hako ${ }^{a}$ Minuteman & $x-839$ & $85-130$ & \\
\hline Hako Minuteman & $\times 1000-15$ & 100 & \\
\hline Hako Minuteman & $M X-1000$ & 100 & \\
\hline Hako Minuteman & $x-1000$ & 130 & \\
\hline Hako Minuteman & $M X-100$ & 130 & Wet \& Dry \\
\hline Nilfiskb & GS-80 & 87 & \\
\hline Nilfisk & GS-82 & 191 & \\
\hline Nilfisk & GS-83 & $208-286$ & \\
\hline Nilfisk & $V T-60$ & 99 & Wet \& Dry \\
\hline Nilfisk & Explosion Proof & 130 & $\begin{array}{l}\text { ExpTosion Proof/Dust } \\
\text { Ignition Proof }\end{array}$ \\
\hline Power Products & Rad $\operatorname{Vac}^{c} 2000$ & 180 & . \\
\hline Euroclean & UZ-930 & 77 & \\
\hline Euroclean & UZ-948 & 270 & \\
\hline Euroclean & UZ-848 & 105 & \\
\hline Euroclean & $U Z-878 A$ & 100 & \\
\hline
\end{tabular}

a Hako is a registered trademark of Hako-Werke GMBH \& Co., Federal Republic of Germany.

b Nilfisk is a registered trademark of A/S Fisker \& Nielsen, Copenhagen, Denmark.

c. Rad Vac is registered trademark of Power Products and Services Co., Inc. CFM = cubic feet per minute. 
DOE/RL-97-50, Rev. 0 $10 / 97$

1

2

3

4

This page intentionally left blank. 
DOE/RL-97-50, Rev. 0

$10 / 97$

APPENDIX B

HIGH-EFFICIENCY PARTICULATE AIR FILTERED VACUUM-UNIT ASSOCIATED TOOLS FOR RADIOACTIVE CONTAMINATION REMOVAL 
DOE/RL-97-50, Rev. 0 $10 / 97$

1

2

3

4

This page intentionally left blank. 
Table B-1. High-Efficiency Particulate Air Filtered Vacuum Unit Associated Tools for Radioactive Contamination Removal.

\begin{tabular}{|c|c|c|}
\hline TOOL & APPLICATIONS & REMARKS \\
\hline $\begin{array}{l}\text { DEsco Mini Die Grinder with fixed } \\
\text { shroud } \\
2^{\prime \prime} \text { and } 3^{\prime \prime}\end{array}$ & $\begin{array}{l}\text { Removal of hazardous and } \\
\text { nonhazardous coatings, paint } \\
\text { scuffing, surface cleaning and } \\
\text { preparation, weld preparation }\end{array}$ & pneumatic only \\
\hline $\begin{array}{l}\text { DESCO right angle grinder with } \\
\text { floating shroud } \\
3^{\prime \prime}, 5^{\prime \prime} \text { and } 7^{\prime \prime}\end{array}$ & $\begin{array}{l}\text { Removal of hazardous and } \\
\text { nonhazardous coatings, paint } \\
\text { scuffing, surface cleaning and } \\
\text { preparation, weld preparation }\end{array}$ & Pneumatic and electric \\
\hline $\begin{array}{l}\text { DESCO Mini Flush Plate } 2.251 \text { Hub } \\
3 \text { Hubs available } \\
\text { Cutter Hub } \\
\text { Hamer Hub } \\
\text { Roto-Peen Hub }\end{array}$ & $\begin{array}{l}\text { Removal of hazardous and } \\
\text { nonhazardous coatings on structural } \\
\text { steel and concrete, grinding, } \\
\text { abrading, surface preparation and } \\
\text { profiling }\end{array}$ & Pneumatic and electric \\
\hline $\begin{array}{l}\text { DESCO FX Tool } \\
3 \text { Hubs available } \\
\text { Cutter Hub } \\
\text { Hammer Hub } \\
\text { Roto-Peen Hub }\end{array}$ & $\begin{array}{l}\text { Removal of hazardous and } \\
\text { nonhazardous coatings on structural } \\
\text { steel and concrete, grinding, } \\
\text { abrading, surface preparation and } \\
\text { profiling }\end{array}$ & Pneumatic and electric \\
\hline $\begin{array}{l}\text { DESCO Floor Abrador } \\
\text { (Walk behind) } \\
5.25 " \text { and } 10.25 " \\
4 \text { Hubs avai lable } \\
\text { Cutter Hub } \\
\text { Hammer Hub } \\
\text { Roto-Peen Hub } \\
\text { BPH Hub }\end{array}$ & $\begin{array}{l}\text { Removal of hazardous and } \\
\text { nonhazardous coatings, rust and } \\
\text { non-skid, VAT mastic removal, } \\
\text { surface profiling, cleaning and } \\
\text { scarifying and grinding }\end{array}$ & Pneumatic and electric \\
\hline $\begin{array}{l}\text { DESCO Needle Descaler } \\
2 \mathrm{~mm} \text { and } 3 \mathrm{~mm} \text { needles } \\
\text { Hand held, straight shank } 4^{\prime} \text { and } 6^{\prime}\end{array}$ & $\begin{array}{l}\text { Removal of hazardous and } \\
\text { nonhazardous coatings, paint, stucco } \\
\text { and rust. Brick and stonework } \\
\text { cleaning. }\end{array}$ & Pneumatic onty \\
\hline $\begin{array}{l}\text { Nilfisk Dritt shield } \\
\text { fits } 1 / 2^{\prime \prime} \text { and } 3 / 4^{\prime \prime}\end{array}$ & $\begin{array}{l}\text { Dust free drilling into hazardous } \\
\text { and nonhazardous materials }\end{array}$ & $\begin{array}{l}\text { Shroud only (drill not } \\
\text { included) }\end{array}$ \\
\hline Nilfisk Sabre Saw & $\begin{array}{l}\text { Dust free cutting of hazardous and } \\
\text { nonhazardous materials }\end{array}$ & $\begin{array}{l}\text { Electric only. Saw and } \\
\text { shroud sold as one }\end{array}$ \\
\hline $\begin{array}{l}\text { Nilfisk Sawzall Shroud } \\
\text { Fits Milwaukee } 6511 \text { and } 6512\end{array}$ & $\begin{array}{l}\text { Dust free cutting of hazardous and } \\
\text { nonhazardous materials. }\end{array}$ & shroud onty \\
\hline $\begin{array}{l}\text { Nilfisk Oscillating Saw } \\
\text { (Cast Cutter) }\end{array}$ & $\begin{array}{l}\text { Dust free cutting of hazardous and } \\
\text { nonhazardous materials, Asbestos } \\
\text { pipe lagging }\end{array}$ & Pneumat ic and electric \\
\hline $\begin{array}{l}\text { DESCO Surface Preparation Tool } \\
\text { (BPH Tool) }\end{array}$ & $\begin{array}{l}\text { Removal of hazardous and } \\
\text { nonhazardous coatings, weld } \\
\text { preparation }\end{array}$ & Pneumatic and electric \\
\hline Wheelabrator Blastrac* & $\begin{array}{l}\text { Removal of coatings from concrete } \\
\text { surfaces, surface preparation, } \\
\text { scabbling }\end{array}$ & Shot blast type \\
\hline
\end{tabular}

\section{* Wheelabrator and $\mathrm{Bl}$ astrac are a registered trademarks of Wheelabrator} Corporation, LaGrange, Georgia. 
DOE/RL-97-50, Rev. 0

This page intentionally left blank. 
DOE/RL-97-50, Rev. 0

$10 / 97$.

1

2

3

4
APPENDIX C

FACILITY POSSESSION LIMITS - SMEARABLE CONTAMINATION 
This page intentionally left blank. 


\section{Dose Assessment Methodology}

The potential total effective dose for each individual facility (e.g., B Plant Complex, C Tank Farm, T Plant Complex, SX Tank Farm, 100-K East Basin, 100-K West Basin, 325 Building, 340 Complex, etc.) or activity (e.g., D\&D of a building) for all cumulative HVU usage must be less than 0.1 millirem for this NOC approval. Annual possession limits for each facility were calculated for the maximum activity of both alpha and beta/gamma contamination that could be handled by all HVU use at an individual facility (assuming contamination levels were $2,000 \mathrm{dpm} / \mathrm{cm}^{2} \alpha$ contamination and $100,000 \mathrm{dpm} / 100 \mathrm{~cm}^{2} \mathrm{~B} / \mathrm{V}$ contamination) without exceeding a potential dose to the nearest receptor of 0.1 millirem per year. These values were listed as APQs in Table 1.

Surface area will be used to determine activity and dose potential for smearable contamination. Fixed contamination is addressed in Appendix $D$. The $A P Q s$ in Table 1 are based on the total amount of activity combined from both smearable and fixed contamination removal.

\section{Calculation of Curie Content for Smearable Contamination.}

Before using HVU equipment for vacuuming of hard surfaces with smearable contamination, estimates must be made of the curie content of the removable contamination and compared to the facility possession limits in Table 1 . Please note that the APQs are an annual limit for all combined HVU use at an individual facility.

To estimate the radioactive contamination, smears must be taken of the surface to be vacuumed. The surface must be adequately surveyed to ensure that the area is not a high contamination area. To be conservative, the alpha contamination can be assumed to be plutonium-239, and beta/gamma contamination can be assumed to be strontium-90. To find the total number of curies for each isotope, use the following formula:

$$
\begin{aligned}
& \text { Curies }=\frac{\text { Surface area vacuumed }\left(\mathrm{m}^{2}\right) * \text { highest contamination }\left(\mathrm{dpm} / 100 \mathrm{~cm}^{2}\right)}{\left(1 \mathrm{E}-04 \mathrm{~m}^{2} / \mathrm{cm}^{2} * 1 \mathrm{dpm} / 2.22 \mathrm{E}-12 \mathrm{Ci}\right)} \\
& =\mathrm{SA} \text { Vacuumed }\left(\mathrm{m}^{2}\right) * \text { max contam. }\left(\mathrm{dpm} / 100 \mathrm{~cm}^{2}\right) * 2.22 \mathrm{E}-8\left(\mathrm{C} j^{*} \mathrm{~cm}^{2} / \mathrm{m}^{2} * \mathrm{dpm}\right) .
\end{aligned}
$$

Example:

A proposed job involves vacuuming a hard surface in a contamination area of $500 \mathrm{~m}^{2}$. The highest smear found was $1000 \mathrm{dpm} / 100 \mathrm{~cm}^{2}$ alpha contamination, and $50,000 \mathrm{dpm} / 100 \mathrm{~cm}^{2}$ beta/gamma contamination.

$$
\begin{aligned}
& { }^{239} \mathrm{Pu}=500 \mathrm{~m}^{2} * 1000 \mathrm{dpm} / 100 \mathrm{~cm}^{2} * 2.22 \mathrm{E}-8 \mathrm{Ci} \mathrm{cm}^{2} / \mathrm{m}^{2} \mathrm{dpm}=1.1 \mathrm{E}-4 \mathrm{Ci} . \\
& { }^{90} \mathrm{Sr}=500 \mathrm{~m}^{2} * 50,000 \mathrm{dpm} / 100 \mathrm{~cm}^{2} * 2.22 \mathrm{E}-8 \mathrm{Cj} \mathrm{cm}^{2} / \mathrm{m}^{2 *} \mathrm{dpm}=5.6 \mathrm{E}-3 \mathrm{Ci} .
\end{aligned}
$$

The curie amounts (estimated from any of the approaches suggested in Appendices $C$ or D) will be added to the total curies to date for any other applicable HWU activity at a given individual facility, and compared to the annual possession limits in Table 1 . If the total curies to date are less 
1 than the APQ, the job could proceed. If the total would exceed the APQ, the 2 job exceeds the scope of this NOC, and a separate approval would be required.

3

HVUs aiso are approved for use in void reduction. The curie amounts can be estimated for these cases with the following certain conservative assumptions.

- An example of this is when a glove bag is installed over equipment for repair or replacement. After the work is complete, the equipment is decontaminated as required. A smear of the interior surface of the glove bag is taken, and the estimated curie contamination on the surface of the glove bag can be used in the previous equations to estimate potential curies released.

- A second example is when a HVU is used to remove excess air from plastic-wrapped, low-level radioactive waste for disposal. An estimate of the curie content of the package is generated before waste acceptance. Because the HVU is not being used to suck up contamination, but rather to leave contamination in place, removing only excess air, a release factor of $1.0 \mathrm{E}-3$ is appropriate. The total curie content of the waste, divided by 1,000 , is a conservative estimate of potential curies released.

HVUs also are approved when a HVU is used to collect exhaust from a pipe that is being swiped with a sponge type ball to verify that the pipe can be released as nonradiologically contaminated. The surface area of the pipe and the contamination on the swipe can be used to estimate potential curies released. 
DOE/RL-97-50, Rev. 0

$10 / 97$

1
2
3
4

APPENDIX D

FACILITY POSSESSION LIMITS - FIXED CONTAMINATION REMOVAL 
This page intentionally left blank. 
I Calculation of Curie Content for Fixed Contamination.

Before using HVU assisted shrouded tools for removal or penetration of fixed contamination, estimates must be made of the curie content in the fixed contamination surface and compared to the APQs in Table 1. Please note that the possession limits are an annual limit for all HVU use at an individual facility.

\section{Alpha and Beta Contamination}

To estimate the radioactive contamination, samples will be taken, composited, and analyzed for total alpha and beta before proceeding. Samples should be taken manualiy (by scraping, chipping, etc., using hand tools only) to the depth of removal for the proposed job and an appropriate surface area (e.g., $25 \mathrm{~cm}^{2}$ each), representative of the area and depth of fixed contamination removal/penetration. Multiple samples could be used for large areas; suggested sampling guidance is provided in Table D-1. Note that the sample collection area must be included in the APQ calculation.

Table D-1. Sampling Guidance

\begin{tabular}{|c|c|}
\hline Surface area (square meters) & $\begin{array}{c}\text { Number of samples } \\
\text { square centimeters each) }\end{array}$ \\
\hline Jess than 0.25 & 1 \\
\hline 0.25 to 0.50 & 2 \\
\hline 0.50 to 0.75 & 3 \\
\hline 0.75 to 1.0 & 4 \\
\hline greater than 1.0 & $4 /$ square meter \\
\hline
\end{tabular}

All the samples for a proposed job will be composited and analyzed for total alpha and beta. To be conservative, the alpha contamination can be assumed to be plutonium-239, and beta/gamma contamination can be assumed to be strontium-90 (facilities that have isotopic information indicating americium-241 to be significant should assume alpha contamination is americium-241, adjusting calculations with appropriate unit dose factors, e.g., multiply americium-24l curies by 1.5 to give equivalent plutonium-239 curies). To find the total number of curies for each isotope, use the following formula:

$$
\text { Curies }=\frac{\text { Total area of fixed contamination removal }\left(\mathrm{m}^{2}\right) * \text { Curies analyzed }}{\text { (number of samples } * 25 \mathrm{~cm}^{2} * 1 \mathrm{E}-04 \mathrm{~m}^{2} / \mathrm{cm}^{2} \text {. }}
$$




\section{Example:}

A proposed job involves removal of fixed contamination in an area of $2 \mathrm{~m}^{2}$. The analysis from the eight samples $\left(25 \mathrm{~cm}^{2}\right)$ taken resulted in a total alpha content of $2 \mathrm{E}-7 \mathrm{Ci}$, and total beta/gamma content of $4 \mathrm{E}-5 \mathrm{Ci}$.

$$
\begin{aligned}
& { }^{239} \mathrm{Pu}=\frac{2 \mathrm{~m}^{2} * 2 \mathrm{E}-7 \mathrm{Ci}}{8 \text { samples } * 25 \mathrm{~cm}^{2} * 1 \mathrm{E}-04 \mathrm{~m}^{2} / \mathrm{cm}^{2}}=2 \mathrm{E}-5 \mathrm{cj} . \\
& { }^{90} \mathrm{Sr}=\frac{2 \mathrm{~m}^{2} * 4 \mathrm{E}-5 \mathrm{Ci}}{8 \text { samples } * 25 \mathrm{~cm}^{2} * 1 \mathrm{E}-04 \mathrm{~m}^{2} / \mathrm{cm}^{2}}=4 \mathrm{E}-3 \mathrm{Ci} .
\end{aligned}
$$

The curie amounts (estimated from any of the approaches suggested in Appendices $C$ or D) will be added to the total curies to date for any other applicable HVU activity at a given facility, and compared to the APQs in Table 1. If the total curies to date is less than the APQ, the job could proceed. If the total would exceed the APQ, the job exceeds the scope of this NOC, and a separate approval would be required.

\section{Gamma Contamination}

For fixed contamination removal/penetration involving gamma contamination only, the previous method can be used. As an alternative, a gamma survey of the site will be sufficient. The gamma survey must be able to account for the contamination to the full depth of removal. Unless the isotope is known, a conservative assumption is made that the contamination is cesium-137, but has the same potential offsite dose as strontium-90.

Using the appropriate efficiencies and detector areas for the survey instruments used, report the activity for direct contact readings in $\mathrm{dpm} / 100 \mathrm{~cm}^{2}$. Table $\mathrm{D}-2$ lists the number of survey sites suggested for given surface areas.

Table D-2. Survey Guidance.

\begin{tabular}{|c|c|}
\hline Surface area (square meters) & $\begin{array}{c}\text { Number of survey sites } \\
\text { (dpm/100 square centimeters) }\end{array}$ \\
\hline Tess than 0.25 & 1 \\
\hline 0.25 to 0.50 & 2 \\
\hline 0.50 to 0.75 & 3 \\
\hline 0.75 to 1.0 & 4 \\
\hline greater than 1.0 & $4 /$ square meters \\
\hline
\end{tabular}

Take the average survey reading for a proposed job, and multiply the $\mathrm{dpm} / 100 \mathrm{~cm}^{2}$ value by $4.5 \mathrm{E}-09$ to get $\mathrm{Ci} / \mathrm{m}^{2}$. To find the total number of curies for ${ }^{90} \mathrm{Sr}$, use the following formula:

Curies $=$ Total area of fixed contamination removal $\left(\mathrm{m}^{2}\right) *$ Average $\mathrm{Ci} / \mathrm{m}^{2}$. 
Example:

2

$2 \mathrm{~m}^{2}$. The survey readings were 3,$500 ; 2,000 ; 3,000 ; 1,000 ; 20,000 ; 4,000$; 2,500 ; and $60,000 \mathrm{dpm} / 100 \mathrm{~cm}^{2}$. The average reading is $12,000 \mathrm{dpm} / 100 \mathrm{~cm}^{2}$, which equals $5.4 \mathrm{E}-5 \mathrm{Ci} / \mathrm{m}^{2}$. The total beta/gamma content could be conservatively estimated at of $1.1 \mathrm{E}-4 \mathrm{Ci}$ of ${ }^{90} \mathrm{Sr}$.

The curie amounts (estimated from any of the approaches suggested in Appendices $C$ or D) will be added to the total curies to date for any other applicable HVU activity at a given individual facility, and compared to the annual possession limits in Table 1. If the total curies to date are less than the $A P Q$, the job could proceed. If the total would exceed the APQ, the job exceeds the scope of this NOC, and a separate approval would be required. 
D0E/RL-97-50, Rev. 0 $10 / 97$

2

3

This page intentionally left blank. 
APPENDIX E

3

EXAMPLE LOG SHEET FOR TRACKING HIGH-EFFICIENCY PARTICULATE AIR FILTERED VACUUM UNIT USE AND ANNUAL POSSESSION QUANTITIES 


\section{DOE/RL-97-50, Rev. 0}

$10 / 97$

This page intentionally left blank. 


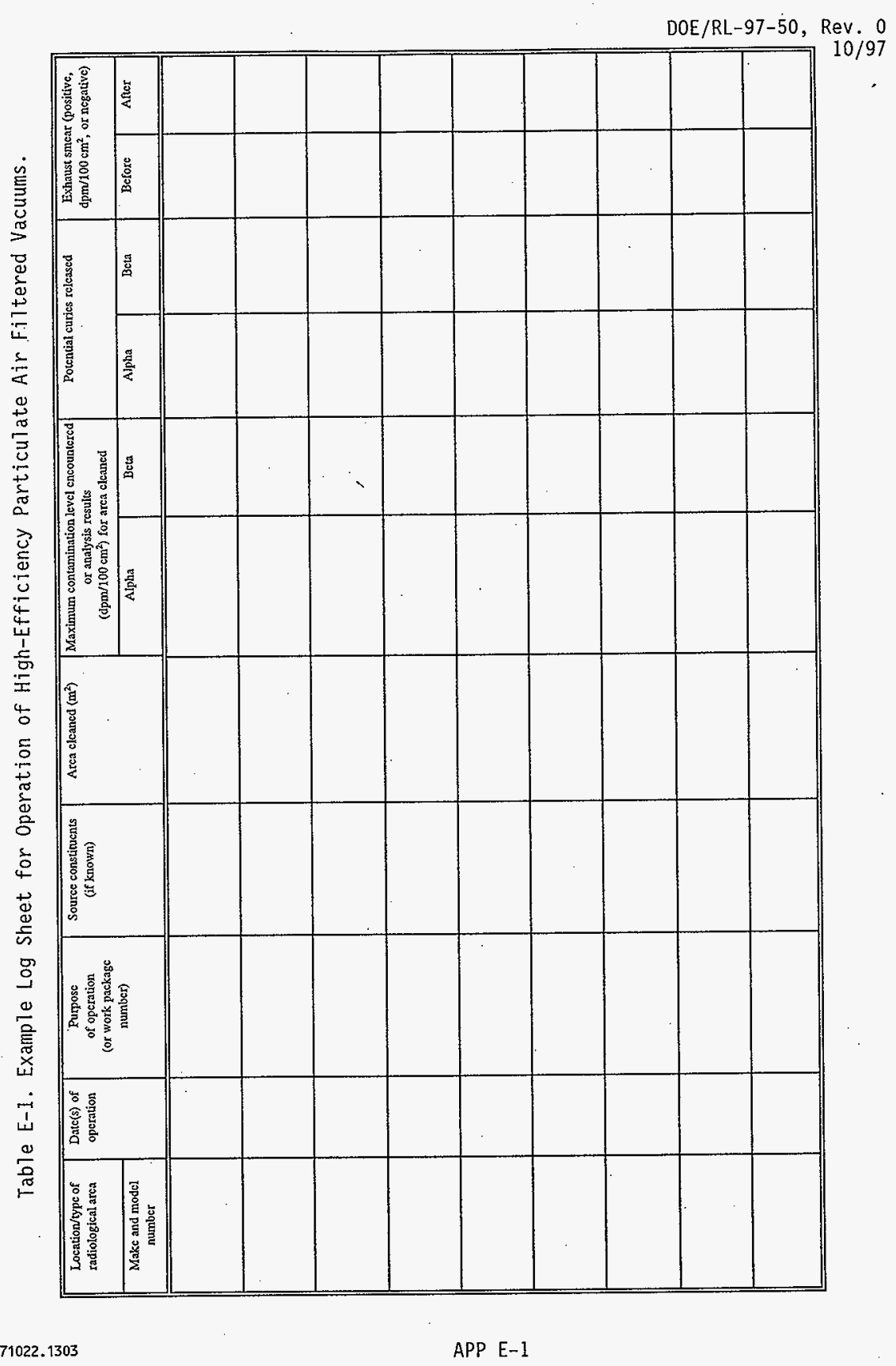


This page intentionally left blank. 


\section{DISTRIBUTION}

Mr. A. W. Conklin, Head

Air Emissions and Defense Waste Section

Division of Radiation Protection

State of Washington

Department of Health

P. 0. Box 47827

07ympia, Washington 98504-7827

Mr. Jerry Leitch, Chief

Radiation and Indoor Air Section

U.S. Environmental Protection Agency

Region 10

1200 Sixth Avenue

Seattle, Washington 98101

J. Witkinson

Confederated Tribes of the Umatilla

Indian Nation

P. 0. Box 638

Pendleton, Oregon 97801

D. Powaukee

Nez Perce Tribe

P. 0. Box 365

Lapwai, Idaho 93540

R. Jim, Manager

Environmental Restoration/

Waste Management Program

Yakima Indian Nation

P. 0. Box 151

Toppenish, Washington 98948

ONSITE

U.S. Department of Energy, Richland Operations office

G. M. Bell

A 5-52

S. D. Bradley

S7 -51

C. E. Clark

A5-15

A. V. Ingle

A5-15

H. M. Rodriguez (10)

A5-15

Reading Room (2)

$\mathrm{H} 2-53$ 
Pacific Northwest National Laboratory

T. W. Moon

J. M. Nickels

G. A. Simiele

Hanford Technical Library

P7-68

P7-68

P7-68

K1-11

Bechtel Hanford. Inc.

R. J. Landon (5)

J. G. Woolard

HO- 02

HO-17

Fluor Daniel Hanford, Inc.

J. A. Bates (2)

H6-23

E. W. Gerber

J. W. Golden

R3-11

T. 3. Harper

N1-26

A. M. Hopkins

H8-69

C. G. Mattsson

$\mathrm{N} 1-26$

R. $\mathrm{Ni}$

N1-26

L. J. Olguin

GI -17

G. W. Reddick

$\mathrm{N} 1-26$

F. A. Ruck III

N1-26

H6-23

M. C. Skriba

H8-68

R. J. Swan

A. M. Umek

H6-23

$57-40$

L. 0 . Waggoner (5)

So-19

J. D. Williams

S7-40

N. H. Williams

R3-11

B. D. Williamson

B3-15

B\&W Hanford Company

P. K. Aardal

T5-54

T. J. Beam

S4-66

R. W. Berk

L5-32

T. A. Dillhoff

N2 -57

K. A. Hadley (5)

R3-56

S. E. Killoy

S6-60

G. J. LeBaron

S6-15

D. J. McBride

T5-15

D. E. Rasmussen

N1-47

J. R. Robertson

T5-54

C. D. Sorensen

T5-57

R. D. Weissenfels

56-60 


\section{DISTRIBUTION (cont)}

MSIN

DE\&S Hanford, Inc.

R. G. Gant

$\times 3-79$

P. G. LeRoy

R3- 15

D. J. Watson (5)

$\times 3-79$

Dyncorp Tri-Cities Services, Inc.

B. J. Dixon

G3-26

D. L. Klages

S4 -56

L. S. McDanieT

G3-25

Lockheed Martin Hanford Corp.

M. S. Allen

S7-01

J. M. Barnett

T4-08

D. J. Carrell

M. L. Dexter

B. G. ErTandson (5)

R1-5I

C. J. Grando

R1-51

E. E. Mayer

R1-51

R. K. P'Pool

R1-51

$\mathrm{R} 2-36$

55-03

Numatec Hanford Corporation

A. R. Hawkins

H5-25

Waste Management Federal Services of Hanford. Inc.

B. M. Barnes

T4-04

R. J. Boom

H. C. Boynton

B. L. Curn

W. E. Davis

D. P. Fassett

D. L. Flyckt

T. P. Frazier

D. W. Fritz (5)

E. M. Greager

J. S. Hil1

N. A. Homan

T6-12

T4-52

H6-36

H6-36

T3-28

S6-71

H6-25

H6- 36

H6-36

H6-25

J. J. Luke

H6-25

H6- 25

R. E. Johnson (10)

H6-25

L. D. Kamberg

H6-25

J. McCoy

K. M. McDonald

H6-21

J. K. Perry

T4-04

D. L. Renberger 


\section{DISTRIBUTION (cont)}

MSIN

Waste Management Federal Services of Hanford, Inc. (cont)

R. W. Szelmeczka L6-05

K. S. Tollefson

T6- 12

D. B. VanLeuven

$\mathrm{H} 6-10$

J. A. Winterhaider

H6-21

Air Operating Permit File

H6-25

Lockheed Martin Services, Inc.

Central Files

B1-07

DPC

H6-08

EDMC H6-08

Waste Management Federal Services, Inc., Northwest Operations

J. J. Dorian

HI-13 